\title{
Fermentation Kinetics of Isolate Lactic Acid Bacteria Probiotic BR 12 and BR 17 were Isolated from Broiler Chicken Meat
}

\author{
Roisu Eny Mudawaroch ${ }^{1}$, Setiyono Setiyono ${ }^{2}$, Lies Mira Yusiati³, \\ Edi Suryanto ${ }^{4}$ \\ \{roisueny@umpwr.ac.id ${ }^{1}$, setiyono@ugm.ac.id ${ }^{2}$, liesmira@ugm.ac.id ${ }^{3}$,edi_ugm@ac.id ${ }^{4}$ \} \\ ${ }^{1}$ Universitas Muhammadiyah Purworejo, Purworejo, Indonesia \\ 2,3,4 Universitas Gadjah Mada Fakultas Perternakan,Yogyakarta, Indonesia
}

\begin{abstract}
The purpose of this study was to determine the Lineweaver-Burk equation, maximum speed $\left(\mu_{\max }\right)$ and maximum specific / per hour growth rate Ks (constant saturation) of probiotic lactic acid isolates BR 12 and BR 17 with limited sucrose. The material in this study was probiotic isolates of Lactic Acid Bacteria (LAB) BR 12 and BR 17 which were isolated from broiler chicken meat, determined media, and sucrose. The method used was growed probiotic LAB isolates in the media determined with a sukora concentration that wasdifferent from $0-1 \%$. The results showed that the Lineweaver-Burk equation of the LAB probiotic BR 12 was $y=3.503 x+10.10$. the maximum speed $\left(\mu_{\max }\right)$ LAB probiotic BR 12 was 0.0075 hour-1 and the constant Michaelis-Menten (KS) was $0.264 \mathrm{~g} / 100 \mathrm{ml}$. Lineweaver-Burk equation of LAB probiotic BR 17 was $\mathrm{y}=2.809 \mathrm{x}+11.40$. The maximum speed $(\mu$ maks $)$ of LAB probiotics BR 17 was 0.088 / hour and the Michaelis-Menten constant $(\mathrm{Km})=0.2464 \mathrm{~g}$ / $100 \mathrm{ml}$. The conclusion of this study was that the Lineweaver-Burk equation BR 12 was different from BR 17. The value of $\mu_{\max }$ and Ks BR 17 was lower than BR 12.
\end{abstract}

Keywords: Fermentation Kinetics, Lactobacillus Fermentum BR 17, Broiler Chicken Meat.

\section{Introduction}

Lactic Acid Bacteria (LAB) were Gram positive, non-spore, negative catalytic, anaerobic, microaerophilic or aero-tolerant and they produce lactic acid as the main product of fermentation [1]. Lactic acid bacteria can grow in plants [2], fish [3] and animals [4]. Lactic Acid Bacteria (LAB) wasone organism that ferments food ingredients through carbohydrate fermentation and generally produces large amounts of lactic acid. These bacteria contribute significantly to the increase in taste and texture of fermented products [5]. Isolates of BR 12 and $\mathrm{BR} 17$ were probiotic $\mathrm{LAB}$ isolated from broiler chicken meat. Isolates isolated from meat can be used as starters in meat fermentation [6]. Fermented meat, which wasa fermented sausage, usually uses sucrose as an energy source for LAB [7]. One thing that wasneeded so that the enzymatic reaction can run efficiently wasto estimate the amount of substrate needed [8]. So, it wasimportant to know the need for sucrose as an energy source for the growth of probiotic LAB isolates BR 12 and BR 17.

The success of the fermentation process wasstrongly influenced by the success in optimizing the desired microbial growth factors. These factors will provide different conditions for each microbe according to their respective environment so that it affects the 
fermentation kinetics [9]. Fermentation kinetics can provide information about the speed of cell biomass production and environmental influences on growth rates [10]. Fermentation kinetics in used substrate can be measured used the Michealis-Menten equation [11].

$$
v=\frac{d[F]}{d}
$$

The kinetics of bacterial growth can also be calculated used a monod equation which was an analogy of the Micheais-Menten equation used enzyme kinetics [12]. The Monod equation was often used to describe the relationship between growth and substrate concentration. The monod equation model is:

$$
\mu=\mu \max \frac{\mathrm{S}}{\mathrm{Ks}+\mathrm{S}}
$$

The value of $\mu$ shows the specific value of the growth rate, $\mu_{\max }$ was the maximum speed, $\mathrm{S}$ was the concentration of the substrate given. The value of $K_{s}$ was the level of $S$ equal to $\mu$ half $\mu \mathrm{mak}$, the value of $K_{s}$ in the monod equation was an analogy of $K_{m}$ in the MichealisMenten equation model. The $\mathrm{K}_{\mathrm{s}}$ value reflects the proportional relationship that bacteria make in used the substrate for growth [13].

The study of the growth kinetics of microbial culture can be used to estimate the efficiency of production costs in large scale [9]. $\mathrm{V}_{\max }$ lipase enzyme with coconut oil substrate of $2.11 \times 10-3 \mathrm{mmol} /$ minute, palm oil substrate $2.30 \times 10-3 \mathrm{mmol} /$ minute on and olive oil substrate $1.60 \times 10-3 \mathrm{mmol} /$ minute on [8]. The pancreatic lipase $\mathrm{K}_{\mathrm{m}}$ value obtained was 1.21 $\times 104 \mathrm{ppm}$ in coconut oil; $2.29 \times 104 \mathrm{ppm}$ on palm oil; and $1.60 \times 104 \mathrm{ppm}$ in olive oil. The cellulase kinetics of Actinomycetes acp-7 isolates in solid rice straw media obtained $\mu_{\max }$ by $31.25 \mathrm{~g}$ per $\mathrm{K}$ at $74.34 \mathrm{~g}$ [14]. The lactic acid bacterial fermentation of $\mathrm{t} 5$ isolates derived from tempoyak obtained $\mu_{\max }$ by 0.0598 (hour-1) while the $\mathrm{K}_{\mathrm{s}}$ value was $1.2236 \mathrm{~g} / \mathrm{g}$ [9].

The purpose of this study was to find out $\mu_{\max }$ (maximum specific growth rate / per hour) and isolate $\mathrm{K}_{\mathrm{s}}$ (constant saturation) $\mathrm{LAB}$ probiotic BR 12 and BR 17 with limited sucrose.

\section{Materials and Methods}

Liquid fermentation isolates from BR 12 and BR 17 used limited sucrose medium. LAB isolates that have been grown with medium defined in hungate tubes [15]. The difined medium consists of

1. Mineral solution I :

$\mathrm{KH}_{2} \mathrm{HPO}_{4}=0.101$

2. Mineral solution II :

$$
\begin{aligned}
& \mathrm{KH}_{2} \mathrm{HPO}_{4}=0.101 \\
& \left(\mathrm{NH}_{4}\right)_{2} \mathrm{SO}_{4}=0.1542
\end{aligned}
$$$$
\mathrm{MgSO}_{4} .7 \mathrm{H}_{2} \mathrm{O}=0.031611
$$

$\mathrm{CaCl}_{2}=0.0204315$

$\mathrm{NaCl}=0.1542$

The composition of a liquid medium defined:

1. $25.7 \mathrm{ml}$ mineral solution I

2. $25.7 \mathrm{ml}$ mineral solution II

3. $0.34 \mathrm{~g}$ yeast extract

4. $119.17 \mathrm{ml}$ of aqudest 
5. sucrose (according to the level used)

The number of bacteria used in planting in this medium was as much as $10 \%$ of the new planting medium. Sucrose as a source of energy for the growth ofisolates LAB probiotic BR 12 and BR 17 with different concentrations of $0.0 ; 0.1 ; 0.2 ; 0.4 ; 0.6 ; 0.8 ; 1 \%$. The bacteria were then incubated at $37^{\circ} \mathrm{C}$. Each treatment was repeated 3 times. The isolates of $\mathrm{LAB}$ probiotic BR 12 and BR 17 were observed for growth by measured optic density (OD) on a spectrophotometer with a wavelength of $600 \mathrm{~nm}$. Observation was carried out every hour until it reaches the stationary phase.

Determination of the maximum rate $\left(\mu_{\max }\right)$ and the Michaelis-Menten constant $(\mathrm{Km})$ was done used the Lineweaver-Burk curve by graphing the relationship between $(1 / \mathrm{v})$ as the $\mathrm{Y}$ axis against $(1 / \mathrm{S})$ as the $\mathrm{X}$ axis. The data obtained was made regression linear so that the linear line equation was obtained. The slope of linear regression was included in the LineweaverBurk equation, namely $y=a x+b$ to get the maximum rate $\left(\mu_{\max }\right)$ and the Michaelis-Menten $(\mathrm{km})$ constant correctly. $\mu_{\max }$ was obtained from $1 / \mathrm{b}$ while $\mathrm{K}_{\mathrm{m}}$ was obtained from $\mu_{\max } \times$ ax.

\section{Results and Discussion}

\section{a. Growth curve}

Liquid fermentation kinetics of LAB probiotics BR 12 and BR 17 used limited sucrose media were carried out to determine growth kinetics by determined the values of $\mathrm{Ks}$ and $\mu \max$. The growth curve of probiotic BR 12 and BR 17 LAB isolates with sucrose energy sources was shown in Figure 1. and Figure 2. LAB growth was influenced by nutrition. The higher the nutrients available, the higher the growth of BAL isolates, and the longer the stationary phase. Lactic acid bacteria use carbohydrates for their growth and produce the main products of lactic acid [16]. an increase in lactic acid during fermentation was associated with an increase in the value of optical density from LAB growth. Carbohydrate fermentation was caused by enzymatic hydrolysis of bacteria [17].

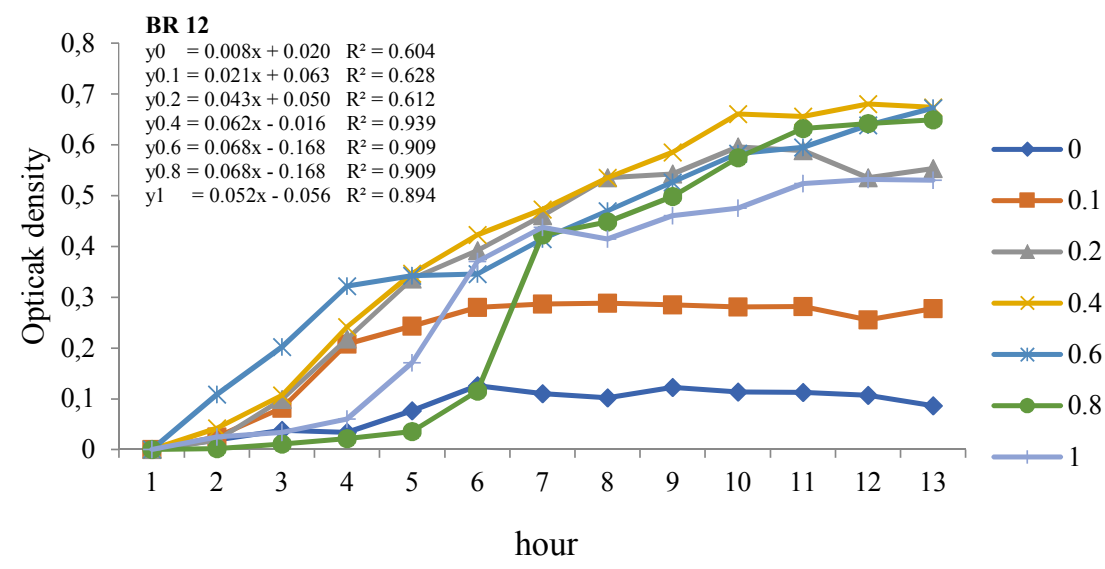

Fig. 1. Graph of growth of BR $12 \mathrm{LAB}$ isolates in liquid form at limited sucrose concentrations $(0 ; 0.1 ; 0.2 ; 0.4 ; 0.6 ; 0.8 ; 1)$. 


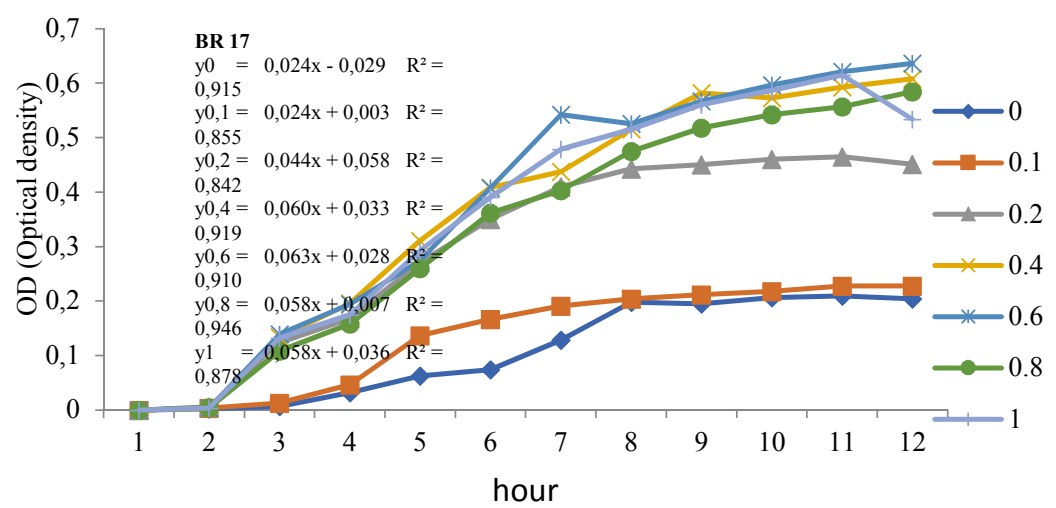

Fig. 2. Graph of growth of $\mathrm{BR} 17 \mathrm{LAB}$ isolates in liquid form at limited sucrose concentrations $(0 ; 0.1 ; 0.2 ; 0.4 ; 0.6 ; 0.8 ; 1)$.

\section{b. The value of $\mu_{\max }$ and Ks}

The kinetic growth of LAB BR 12 and BR 17 was used to measure the reaction rate (Table 1). in table 1 shows that the higher the substrate level, the higher the velocity $\mu$ in the BR 12 and BR 17 LAB, because high energy reserves will accelerate growth. monod equation can be obtained Ks and $\mu$ max values. The values of Ks and $\mu$ max obtained can show the efficiency of media use by LAB probiotics BR 12 and BR 17.

Monod equations describe an increase in $\mu$ when substrate concentration increases and slows down to the maximum specific growth value ( $\mu$ max). When the substrate concentration in the condition $\mu$ was equal to half $\mu_{\max }$, then the saturated concentration of half saturation can be known. Ks value was an important element in the biodegradation process because Ks shows the relationship between affinity value and bacterial cell growth rate [18]. The relationship between $1 /[\mathrm{S}]$ and $1 /[\mu]$ LAB probiotics BR 12 and BR 17 isolates used limited sucrose was illustrated by the Lineweaver-Burk curve, this can be seen in Figure 3.

Table 1. Reaction rates of isolates BR 12 and BR 17

\begin{tabular}{cccccccc}
\hline $\begin{array}{c}\text { Time } \\
\text { (hour } \\
\text { s) }\end{array}$ & $\begin{array}{c}\text { Sucros } \\
\mathrm{e}\end{array}$ & \multicolumn{3}{c}{ Isolate LAB BR 12 } & \multicolumn{3}{c}{ Isolate LAB BR 17 } \\
\cline { 3 - 8 } & $\mu$ & $1 /[\mathrm{S}]$ & $\begin{array}{c}1 / \mu \\
\left.\text { hours }^{-1}\right)\end{array}$ & $\mu$ & $1 /[\mathrm{S}]$ & $\begin{array}{c}1 / \mu \\
\left(\text { hours }^{-1}\right)\end{array}$ \\
\hline 13 & 0,0 & 0.008 & & & 0,023 & & 43,47 \\
13 & 0,1 & 0.021 & 10,00 & 47.61905 & 0,024 & 10,00 & 41,67 \\
13 & 0,2 & 0.043 & 5,00 & 23.25581 & 0,047 & 5,00 & 21,27 \\
13 & 0,4 & 0.062 & 2.50 & 16.12903 & 0,061 & 2.50 & 16,39 \\
13 & 0,6 & 0.068 & 1.67 & 14.70588 & 0,064 & 1.67 & 15,62 \\
13 & 0,8 & 0.068 & 1.25 & 14.70588 & 0,059 & 1.25 & 16,95 \\
13 & 1,0 & 0.052 & 1,00 & 19.23077 & 0,060 & 1,00 & 16,67 \\
\hline
\end{tabular}

Based on the graph in Figure 3, the BR 12 equation, $y=3.503 x+10.10, R^{2}=0.918$ and BR 17 were $\mathrm{y}=2.809 \mathrm{x}+11.40, \mathrm{R}^{2}=0.928$, the maximum value of $\mathrm{LAB}$ isolates from $\mathrm{BR}$ 12 probiotic isolates was $0.099 /$ hour and BR 17 was 0.088 / hour. Specific speed of probiotics LAB BR 17 was higher than probiotics LAB BR 12. This speed difference was caused by genetic variation. Constant Michaelis-Menten (Ks) BR 12 was $0.34 \mathrm{~g} / 100 \mathrm{ml}$ and 
BR 17 was $0.246 \mathrm{~g} / 100 \mathrm{ml}$. The Ks value in this study was still below Ks LAB. The Ks value of $\mathrm{LAB}$ ranges from $0.3-4.5 \mathrm{~g} / 100 \mathrm{ml}$ [19]. The Ks value indicates that BR 12 requires sucrose of $0.099 \mathrm{~g}$ in every $100 \mathrm{ml}$ of media to produce optimal bacterial growth rates, whereas BR 17 requires sucrose $0.246 \mathrm{~g}$. BR 17 isolates require fewer sucrose substrates compared to BR 12, this was due to genetic variation. The results of this study indicate that the growth rates of BR 12 and BR 17 on the sucrose substrate were low. this was because sucrose was disaccharide so its use must be broken down into monosaccharide [20].

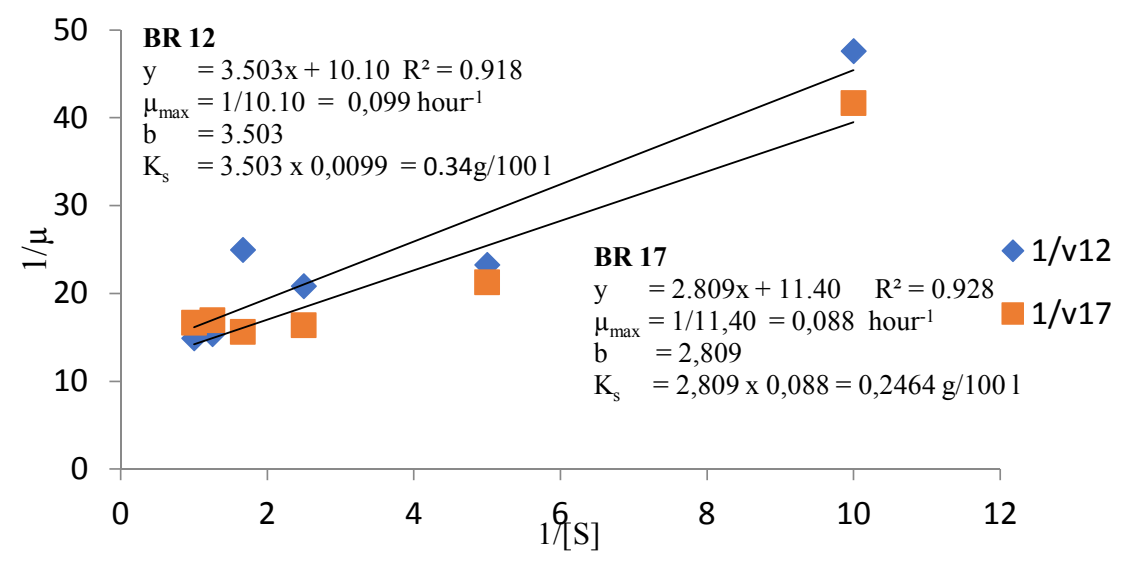

Fig. 3. Lineweaver-Burk curve between $1 /[\mathrm{S}]$ and $1 /[\mu] \mathrm{LAB}$ probioticBR 12 and BR 17 used limited sucrose.

\section{Conclution and Suggestion}

\section{a. Conclusion}

The conclusion of this study were that the LAB BR 12 and BR 17 fermentation kinetics isolated from chicken showed Lineweaver-Burk equation BR 12 different BR 17. The value of $\mu_{\max }$ BR 17 was lower than BR 12, and Ks BR 17 was lower than BR 12.

\section{b. Suggestion}

More research was needed to determine the specific characteristics of isolates BR 12 and BR 17 which were seen in terms of growth kinetics.

\section{Conclusion}

This work was supported by Indonesian Higher Education Research and Technology (RISTEKDIKTI) in the 2017/2018 doctoral dissertation research program (PDD).

\section{References}

[1] Khalid, K. An Overview of Lactid Acid Bacteria. International Journal of Biosciences (IJB). Vol. 1 no. 3, pp. 1-13, 2011.

[2] Kuda, T., M. Kataoka, M. Nemoto, M. Kawahara, H. Takahashi and B. Kimura. Isolation of lactic acid bacteria from plants of the coastal Satoumi regions for use as starter cultures in fermented milk and soymilk production. Food Sci. and Technol. Vol. 
68 pp. 202-207, 2016.

[3] Sarika A.R., A.P. Lipton, M.S. Aishwarya, and R.S. Rachana. Lactic Acid Bacteria from Marine Fish: Antimicrobial Resistance and Production of Bacteriocin Effective Against L. monocytogenes In Situ. J Food Microbiol Saf Hyg Vol. 2 no 128. doi:10.4172/24762059.1000128, 2017.

[4] Miranda J.M., A. Samuel, C.G. Nebot A. Cepeda, and C.M. Franco Technological Characterization of Lactic Acid Bacteria Isolated from Beef Stored on VacuumPackaged and Advanced Vacuum Skin Packaged System. J Food Process Technol Vol. 5, pp. 338, doi:10.4172/2157-7110.1000338, 2014.

[5] Sharaf, O.M., K. El-Shafie, G.A. Ibrahim, B.A. Effat, M.A. Abd El-Mageed, Mansour, A.F., M.S. Shahein, H.A. Shaaban, K. F. El- Massrey, F.M. Osman and A.H. ElGhorab. Isolation, Identification and Selection of Lactic Acid Bacteria Cultures for Production of Food Aroma \& Flavour Australian Journal of Basic and Applied Sciences, Vol. 6 no. 6, pp. 183-203, 2012.

[6] Menegas LZ, T.C. Pimentel, S. Garcia and S.H. Prudencio. Dry-fermented chicken sausage produced with inulin and corn oil: physicochemical, microbiological, and textural characteristics and acceptability during storage. Meat Sci. Vol. 93 no. 3, pp. 501-6, 2013. doi: 10.1016/j.meatsci. 11.003, 2012.

[7] Zagorec, M. and M. Champomier-Vergès. Lactobacillus sakei: A Starter for Sausage Fermentation, a Protective Culture for Meat Products. Microorganisms. Vol. 5 pp. 5669, doi: 10.3390/microorganisms5030056, 2017.

[8] Ratnayani, K., A.A. I. A. M. Laksmiwati, dan M. Sudiarto. Penentuan laju reaksi maksimal (vmaks) dan konstanta michaelis-menten $(\mathrm{km})$ enzim lipase pankreas pada substrat minyak kelapa, minyak sawit, dan minyak zaitun. Jurnal Kimia Vol. 9 no. 1, pp. 93-97, 2015.

[9] Yuliana, N.Growth Kinetic of Lactic Acid Bacteria, Isolate T5 Originated from Tempoyak. J. Tek. Industri dan Hasil Pertanian Vol. 13, no 2, pp. 108-117, 2008.

[10] Pramono,Y.B., E. Harmayani, dan T. Utami. Growth Kinetics of Lactobacillus plantarum and Lactobacillus sp. In MRS medium. J. Teknol. dan Industri Pangan. Vol. 14, pp. 46-50, 2003.

[11] Cornish-Bowden, A. The origins of enzyme kinetics FEBS Letters. Vol. 587(17) pp. 2725-2730 (2013) https://doi.org/10.1016/j.febslet. 06.009, 2013.

[12] Istianah, N. and S. Gunawan. Kinetika Fermentasi Asam Laktat dari Tepung Sorgum Menggunakan Baker's Yeast dan L. Plantarum. J. Rekayasa Bahan Alam dan Energi Berkelanjutan.Vol. 1, pp. 49-55, 2017.

[13] Robinson. P.K. Enzymes: principles and biotechnological applications. Essays Biochem. Vol. 59, pp. 1-41, doi: 10.1042/BSE0590001, 2015.

[14] Satria, H., D. Herasari, and S.D. Yuwono. Kinetika Fermentasi Produksi Selulase Dari Isolat Actinomycetes AcP-7 Pada Media Padat Jerami Padi. Jurnal Kimia dan Kemasan. Vol. 33, pp. 152-156. DOI: 10.24817/jkk.v33i2.1844, 2011.

[15] Paradhipta, D.H.V., Z. Bachruddin, and L.M. Yusiati. Feed Formulation Based on ByProducts: Kinetic Study of Food Industry By-Product on Lactic Acid Fermentation. In: the 16th AAAP Congress, 10-14 November, Yogyakarta, 2014.

[16] Greaser, L. and W. Guo. Postmorten muscle chemistry. In Y.H. Hui eds.Handbook of Meat and Meat rocessing pp. 63 - 79. CRC Press. New York, 2012.

[17] Setiarto, R.H.B., N. Widhyastuti, and N.A. Rikmawati. Concentration Optimization of Fructo oligosaccharides To Increase Growth of Lactic Acid Bacteria Yoghurt Starter). Jurnal Veteriner. Vol. 18, pp. 428-440, 2017. 
[18] Kurniawan, A. and A.J. Effendi. Biodegradasi residu total petroleum hidrokarbon di bawah konsentrasi $1 \%(\mathrm{w} / \mathrm{w})$ hasil proses bioremediasi. J. Manusia dan Lingkungan. Vol. 21, pp. 286-294, 2014.

[19] Moonchai, S., W. Madlhoo, K. Jariyachavalit, H. Shimizu, S. Shioya, and S. Chauvatcharin. Application of a mathematical model and differential evolution algorithm approach to optimization of bacteriocin production by Lactococcus lactis C7. Bioprocess Biosyst. Eng. Vol. 28, pp.15-26, 2005.

[20] Colin G.Scanes, C.G. Chapter 18 -Carbohydrate Metabolism in Sturkie's Avian Physiology (Sixth Edition). pp. 421-441, https://doi.org/10.1016/B978-0-12-4071605.00018-X, 2015. 